\title{
Research on Evaluation Index System of Green Highway in Reconstruction and Expansion Projects
}

\author{
Yang Yan-gang ${ }^{1, *}$, Xia Jian-ping ${ }^{2}$, Zhao Ran $^{2}$, Li Chen ${ }^{2}$ \\ ${ }^{1}$ Shandong Hi-speed Group Co., Ltd, Shandong, Jinan, 2500002 \\ ${ }^{2}$ China Academy of Transportation Science, Beijing, 100029
}

\begin{abstract}
This study summarizes and condenses the core requirements of green road construction in the reconstruction and expansion project, systematically analyzes the three typical representative green road evaluation index systems of GreenRoads, INVEST and Green-LITES. A green highway evaluation index system including 7 first-level indicators, 20 second-level indicators, and 52 third-level indicators has been constructed, The analytic hierarchy process was used to establish a step-level model, the relative importance of each index is determined according to the judgment of experts, and the weight coefficient of each level of index is obtained. In terms of policy requirements, related technology applications, green highway development trends, and the actual construction of the Beijing-Shanghai Expressway reconstruction and expansion project, the three-level indicator scoring method was determined. The green highway evaluation index system and evaluation model were used to evaluate the reconstruction and expansion project of the Beijing-Shanghai Expressway from Laiwu to Linyi (Lu-Sujie). It was determined that the comprehensive score of the project was 81.2, which reaching an excellent level.
\end{abstract}

\section{INTRODUCTION}

The large-scale, high-speed sustainable development of the transportation industry will be restricted by resource and environmental conditions, and the green development needs of transportation industry has become more urgent. The "Guiding Opinions on the Implementation of Green Road Construction" issued by the Ministry of Transport in July 2016, which proposed that the main Characteristic of green road should good quality, resource conservation, ecological environment friendly, energy conservation, and service improvement. The "Guiding Opinions" clarified the construction goals and main tasks of green highways, but there has not been a systematic study of what conditions or standards should be met for green highways, especially for reconstruction and expansion projects.

In terms of green road evaluation indicators, some related research work has also been carried out. 'Greenroads' is the first green road rating system in the United States. It is a voluntary third-party evaluation system initiated by the University of Washington, including 11 mandatory requirements and 37 items. The Netherlands, Germany, France, Britain, Norway, Spain and other countries have also established corresponding energy consumption evaluation systems for the life cycle of road construction projects.

The green roads which derived from green low-carbon roads claimed that road construction should follows the green and low-carbon design concept through planning stage, construction stage, operation and management stage, and should adopting new technologies actively, to achieve the goals of reducing energy consumption and avoiding ecological damage, reducing carbon emissions, and improving environmental benefits during the entire life cycle of the road.

In recent years, researches have concerned about the evaluation index system of green roads. Sun Lei (2012) analyzed the basic connotation of green roads and their differences and connections with ecological roads and landscape roads. Presented core framework of the green highway evaluation index system in four aspects: energy utilization, environmental pollution, ecological destruction, safety and health. And take the environmental elements and ecological elements as the criterion level. Liu Jian (2016) based on the concept of life cycle and built a green low-carbon road evaluation system with 14 main control indicators as mandatory indicators and 21 general indicators as the evaluation framework. Using the evaluation system on a sample green low-carbon road and determine the grade of the green and low-carbon road.

Zhang (2011) adopted the green road evaluation index system established by the PRS model; Wang (2014) constructed a green low-carbon road evaluation system based on the analytic hierarchy process and multi-level fuzzy comprehensive evaluation method, and used it for the Yunnan Ma Zhao green road; Xie (2016) optimized the green and low-carbon highway evaluation index system and proposed the quantitative indicators and the qualitative indicators, and using the analytic hierarchy process to determine the weight of the indicators. The optimized index system was used to evaluate the green and low-carbon grade of Sanxi Expressway.

\footnotetext{
${ }^{\text {* Corresponding author: ecologyoung@ } 126 . c o m}$
} 
The reconstruction and expansion project of the Laiwu-Linyi (Lu-Sujie) section of the Beijing-Shanghai Expressway is one of the only two reconstruction and expansion projects in the second batch of typical green highway demonstration projects of the Ministry of Transport. Different from the new road project, the green road construction of the renovation and expansion project has unique characteristics such as the high demand of keep traffic uninterrupted, high resource reuse requirements, and high resource reuse value. The green road construction of the renovation and expansion project has never been carried out before. the connotation and characteristics of green highways are still unclear and related research technologies are still under exploring, it is urgent to improve the evaluation method, proposed evaluation index system, carry out evaluation and guide the green roads construction of the reconstruction and expansion project.

On the basis of summarizing and inheriting the existing research and experience, this study summarizes and condenses the core requirements of green roads construction of the reconstruction and expansion project, and proposes main indicators and scoring standards of the green road construction of the renovation and expansion project. Using expert scoring and analytic hierarchy process weight assignment method to determine the evaluation index weight, and further calculate the final index score, and then determine the green road construction score of the reconstruction and expansion project of the Beijing-Shanghai Expressway from Laiwu to Linyi ( $\mathrm{Lu} \mathrm{Su} \mathrm{Jie)}$.

\section{CONSTRUCTION OF GREEN HIGHWAY EVALUATION SYSTEM FOR RECONSTRUCTION AND EXPANSION PROJECTS}

\subsection{Selection and determination of index system framework}

This research draws on the structure of the evaluation index system of the US GREENROAD green road index system, the INVEST index system, the Green-LITES, and the "Yunnan Province Green Road Evaluation Standard", the "Hubei Province Green Road Evaluation Index System", the "Jilin Province Green Road index system", center on the eight main characteristics of green roads (intensive resource conservation, optimized energy use, emphasis on ecological protection, pollution control, and cycle costs., Implement innovation-driven, improve project quality, expand service functions). Take ecological protection, pollution prevention, resource conservation, energy saving and carbon reduction, quality construction, service improvement, and innovation support as first-level indicators. Combine the characteristics of the reconstruction and expansion project of Beijing-Shanghai Expressway, screened 20 second-level indicators and 52 third-level indicators, and constructed an evaluation index system for the reconstruction and expansion projects.

\subsection{Construction of Evaluation Index System}

Based on the preliminary green road evaluation index system for the reconstruction and expansion project of the Beijing-Shanghai Expressway from Laiwu to Linyi (LuSujie), we designed a questionnaire on the evaluation index weight and distributed it to experts of transportation, and received a total of 8 valid weight questionnaires. the analytic hierarchy process is used to index weighting. The evaluation index system is divided into 3 levels. The first level takes green road construction as the main goal, and the criterion level contained seven aspects: ecological protection, pollution prevention, resource conservation, energy saving and carbon reduction, quality construction, service improvement, and innovation support. The standard level is broken down into several indicators.

\subsection{Indicators scoring}

The evaluation indicators are scored based on the relative importance between indicators, and the comparison results of the criterion level and the indicator level in each questionnaire are summarized. Obtain the importance score table for the pairwise comparison of the index layer, construct and solve the judgment matrix, and verify the consistency of the results, and obtain the final evaluation index weight table.

\subsection{Determination of evaluation index weight}

According to the pairwise comparison results of the evaluation indexes of each level, they are substituted into the judgment matrix, and finally the weight assignment of each index is obtained.

\section{EMPIRICAL RESEARCH ON GREEN HIGHWAY EVALUATION INDEX SYSTEM}

A test evaluation questionnaire for the evaluation index system of the Beijing-Shanghai Expressway Green Highway was compiled, field surveys were carried out, and design documents, construction organization design, supervision documents and other materials were checked to determine the scoring method for the three-level indicators (omitted). According to the scoring method, determine the scores of each three-level index, and multiply the index weight to obtain the final score of each three-level index (Table 2):

Table 1 Scores of the third level indicators

\begin{tabular}{|c|c|c|c|}
\hline Third-level index weight & Score & weight & Final score \\
\hline Sensitive target avoidance & 0.8 & 1 & 0.8 \\
\hline Road vegetation protection & 1.0 & 0.60 & 0.60 \\
\hline High fill and deep excavation control & 1 & 0.20 & 0.2 \\
\hline
\end{tabular}




\begin{tabular}{|c|c|c|c|}
\hline Tunnel opening control & 1 & 0.20 & 0.2 \\
\hline Vegetation restoration & 0.8 & 0.16 & 0.128 \\
\hline Slope ecological protection & 1 & 0.32 & 0.32 \\
\hline Ecological improvement of drainage facilities & Do not participate in evaluation & 0.21 & 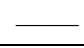 \\
\hline Ecological retaining wall application & 0 & 0.32 & 0 \\
\hline The sewage treatment capacity of auxiliary facilities & Do not participate in evaluation & 0.60 & - \\
\hline $\begin{array}{l}\text { Rebuild and improve road (bridge) surface runoff } \\
\text { collection and treatment facilities }\end{array}$ & 1 & 0.20 & 0.2 \\
\hline Wastewater treatment during construction & 0.8 & 0.20 & 0.16 \\
\hline Dust control during construction & 1 & 0.60 & 0.60 \\
\hline Construction machinery pollution control & 1 & 0.20 & 0.20 \\
\hline Asphalt flue gas control & Do not participate in evaluation & 0.20 & - \\
\hline Noise pollution prevention & 1 & 1.00 & 1 \\
\hline Layout of temporary land use & 1 & 0.30 & 0.3 \\
\hline Zero discards, less debits & 0.5 & 0.70 & 0.35 \\
\hline Recycling of old roads & 0.6 & 0.50 & 0.3 \\
\hline $\begin{array}{l}\text { Utilization rate of concrete materials for demolition } \\
\text { of old roads }\end{array}$ & 0.6 & 0.29 & 0.174 \\
\hline Traffic safety facility utilization & 1 & 0.07 & 0.07 \\
\hline Bridge structure utilization & 1 & 0.15 & 0.15 \\
\hline Real estate materials, industrial waste utilization & 0.8 & 0.33 & 0.264 \\
\hline Template material utilization & 1 & 0.33 & 0.33 \\
\hline Comprehensive utilization rate of tunnel spoil & 0.2 & 0.33 & 0.066 \\
\hline Water reuse in service area & Do not participate in evaluation & 1.00 & $\overline{ }$ \\
\hline Centralized power supply during construction & 1 & 0.25 & 0.25 \\
\hline Mixture energy saving technology & 0.6 & 0.55 & 0.33 \\
\hline Natural gas mixing station & 1 & 0.13 & 0.13 \\
\hline $\begin{array}{c}\text { Energy-saving construction equipment and } \\
\text { technology }\end{array}$ & 1 & 0.07 & 0.01 \\
\hline Tunnel ventilation and energy saving & 1 & 0.14 & 0.14 \\
\hline Lighting energy saving measures & 1 & 0.21 & 0.21 \\
\hline Building energy efficiency measures & Do not participate in evaluation & 0.41 & 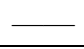 \\
\hline New energy utilization & Do not participate in evaluation & 0.17 & $\overline{ }$ \\
\hline Power supply and distribution system energy saving & 1 & 0.07 & 0.07 \\
\hline Steel structure bridge application & 1 & 0.50 & 0.50 \\
\hline Functional road applications & 0.6 & 0.50 & 0.3 \\
\hline Construction management information & 1 & 0.20 & 0.20 \\
\hline BIM technology application & 1 & 0.60 & 0.6 \\
\hline HSE management system & 1 & 0.20 & 0.20 \\
\hline Process standardization & 1 & 0.50 & 0.50 \\
\hline Site standardization & 1 & 0.50 & 0.50 \\
\hline Traffic warning system & 1 & 1.00 & 1.00 \\
\hline Information Service & Do not participate in evaluation & 0.25 & 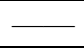 \\
\hline Improved tourism service functions & Do not participate in evaluation & 0.25 & - \\
\hline Shared service area & Do not participate in evaluation & 0.25 & - \\
\hline Humanized facilities upgrade & Do not participate in evaluation & 0.25 & - \\
\hline Landscape display & Do not participate in evaluation & 1.00 & - \\
\hline Scientific research & 1 & 0.66 & 0.66 \\
\hline New Technology Application & 1 & 0.33 & 0.33 \\
\hline Project implementation & 1 & 0.60 & 0.60 \\
\hline Promotion training & 1 & 0.20 & 0.20 \\
\hline Whole process environmental management & 0.5 & 0.20 & 0.1 \\
\hline
\end{tabular}


Sum the third-level index scores under each secondlevel index to obtain the second-level index score (Table $3)$, summarize the second-level index scores under the corresponding first-level index, and multiply the firstlevel index weight to obtain the first-level index score. Then get the relative score of each first-level index, and get the final evaluation score after averaging (Table. 4)

Table 2 Scores of the second level indicators

\begin{tabular}{|c|c|c|c|}
\hline Second-level index & Score & Weight & Score \\
\hline $\begin{array}{l}\text { Sensitive target } \\
\text { avoidance }\end{array}$ & 0.8 & 0.6 & 0.48 \\
\hline $\begin{array}{l}\text { Vegetation and } \\
\text { terrain protection }\end{array}$ & 1 & 0.2 & 0.2 \\
\hline $\begin{array}{l}\text { Ecological } \\
\text { restoration }\end{array}$ & 0.528 & 0.2 & 0.1056 \\
\hline $\begin{array}{c}\text { Water pollution } \\
\text { prevention }\end{array}$ & 0.7 & 0.6 & 0.42 \\
\hline $\begin{array}{l}\text { Air pollution } \\
\text { control }\end{array}$ & 1 & 0.2 & 0.2 \\
\hline $\begin{array}{c}\text { Noise pollution } \\
\text { prevention }\end{array}$ & 1 & 0.2 & 0.2 \\
\hline $\begin{array}{l}\text { Land resource } \\
\text { conservation }\end{array}$ & 0.65 & 0.27 & 0.1755 \\
\hline $\begin{array}{l}\text { Utilization of old } \\
\text { road facilities }\end{array}$ & 0.694 & 0.58 & 0.40252 \\
\hline Material recycling & 0.66 & 0.14 & 0.0924 \\
\hline Water conservation & $\begin{array}{c}\text { Do not } \\
\text { participate } \\
\text { in } \\
\text { evaluation }\end{array}$ & 0.07 & - \\
\hline $\begin{array}{c}\text { Energy saving } \\
\text { during construction }\end{array}$ & 0.78 & 0.5 & 0.39 \\
\hline $\begin{array}{c}\text { Energy saving } \\
\text { during operation }\end{array}$ & 1 & 0.5 & 0.5 \\
\hline Durability & 0.8 & 0.47 & 0.376 \\
\hline $\begin{array}{c}\text { Intelligent } \\
\text { management }\end{array}$ & 0.8 & 0.13 & 0.104 \\
\hline $\begin{array}{l}\text { Standardized } \\
\text { construction }\end{array}$ & 1 & 0.16 & 0.58 \\
\hline $\begin{array}{c}\text { Smart } \\
\text { Transportation } \\
\text { System } \\
\end{array}$ & 1 & 0.14 & 0.88 \\
\hline $\begin{array}{l}\text { Diversified } \\
\text { services }\end{array}$ & $\begin{array}{c}\text { Do not } \\
\text { participate } \\
\text { in } \\
\text { evaluation }\end{array}$ & 0.5 & - \\
\hline $\begin{array}{c}\text { Landscape } \\
\text { optimization }\end{array}$ & 0.6 & 1 & 0.6 \\
\hline $\begin{array}{c}\text { Technological } \\
\text { innovation }\end{array}$ & 1 & 0.5 & 0.5 \\
\hline $\begin{array}{c}\text { Green construction } \\
\text { concept }\end{array}$ & 0.9 & 0.5 & 0.45 \\
\hline
\end{tabular}

Table 3 Scores of the first level indicators

\begin{tabular}{|c|c|c|c|}
\hline First-level index & Weight & Score & $\begin{array}{c}\text { Relative } \\
\text { score } \\
\text { (full } \\
\text { marks) }\end{array}$ \\
\hline ecological protection A & 0.26 & 22.5 & 0.98 \\
\hline pollution prevention B & 0.22 & 18.0 & 0.82 \\
\hline
\end{tabular}

\begin{tabular}{|c|c|c|c|}
\hline resource conservation C & 0.16 & 10.7 & 0.67 \\
\hline $\begin{array}{c}\text { energy saving and carbon } \\
\text { reduction D }\end{array}$ & 0.10 & 8.9 & 0.89 \\
\hline quality construction $\mathrm{E}$ & 0.12 & 10.4 & 0.87 \\
\hline service improvement $\mathrm{F}$ & 0.06 & 3.6 & 0.60 \\
\hline innovation support G & 0.08 & 7.6 & 0.95 \\
\hline Total score & \multicolumn{2}{|c|}{$\mathbf{8 1 . 8}$} & \\
\hline
\end{tabular}

The comprehensive score of the green road construction of the reconstruction and expansion project of the Laiwu-Linyi (Lu-Sujie) section of the BeijingShanghai Expressway is 81.8 points, which meets the "excellent" level of green roads in this evaluation system. This score is calculated based on the current project progress and construction level. With the progress of the project, the final score of this project can be obtained.

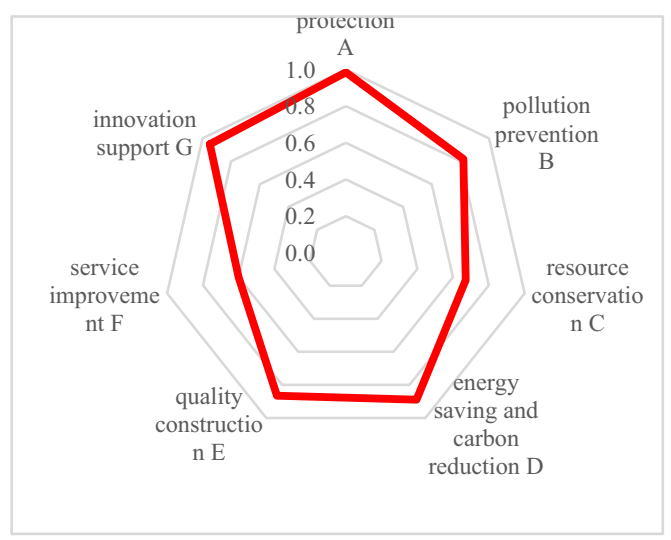

Figure 1 The first-level indicator scores of the effect evaluation of the Beijing-Shanghai high-speed reconstruction and expansion project

The relative scores of the first-level indicators were further analyzed. Among the 7 first-level indicators of the reconstruction and expansion project of the BeijingShanghai Expressway from Laiwu to Linyi (Lu-Su Jie), ecological protection and innovation support score the most prominent, and the scores account for $98 \%$ and $95 \%$ of the full marks, energy-saving and carbon-reduction and quality construction scores are also high, with scores accounting for $89 \%$ and $87 \%$ of the full marks, respectively, all of the above indicators reach the "excellent" level; the service improvement and resource conservation index scores are relatively low (Figure 1). The reason is that the project has not yet been completed and demolition of built roads have not been fully utilized. Due to the lag in the construction of the service area, the service improvement score is not the final score.

Among the second-level indicators, the indicators of durability, material recycling, and utilization of old roads facilities have low scores, accounting for less than $80 \%$ of the full marks. With the further implementation of the project, the above indicators have great potential for improvement (Figure 2). 


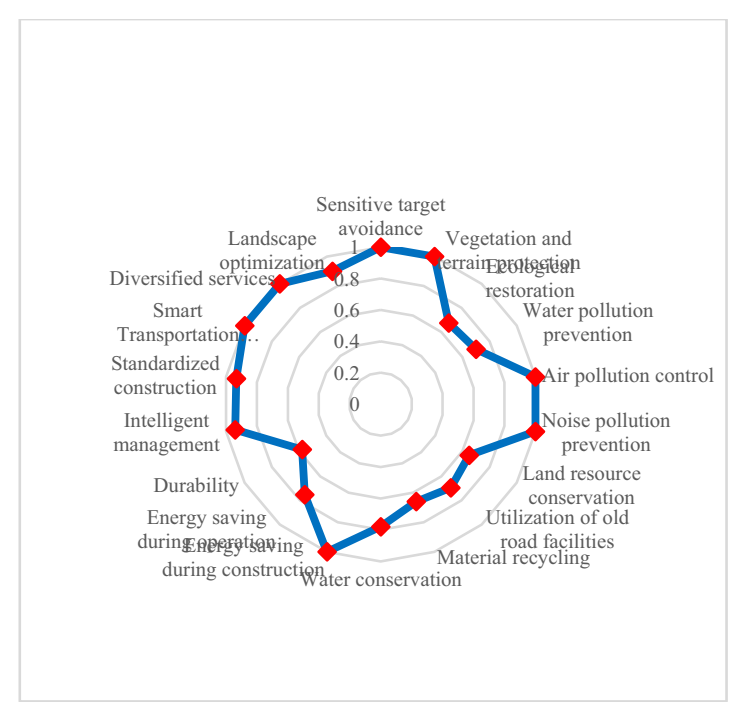

Figure 2 The second-level indicator scores of the effect evaluation of the Beijing-Shanghai high-speed reconstruction and expansion project

\section{CONCLUSION}

This research conducted a systematic analysis of the three typical and representative green road evaluation index systems of GreenRoads, INVEST and Green-LITES, and constructed Evaluation index system for green highways of Beijng-Shanghai Expressway. The first-level of index system were including ecological protection, pollution prevention, resource conservation, energy conservation and carbon reduction, quality construction, service improvement, innovation support, A total of 20 evaluation indicators constitute the second-level indicators, which including sensitive target avoidance, water pollution prevention, land resource conservation, construction energy conservation and carbon reduction, engineering durability, Diversified services, technological innovation etc. A total of 52 evaluation indicators constitute the thirdlevel indicators, which including reuse of auxiliary facilities along the line, centralized power supply during construction period, intensive use of permanent land, etc.

The analytic hierarchy process was used to establish a hierarchy model, and the importance of indicators is quantitatively scaled according to the judgment of experts, and then the relative importance of each indicator is determined. On this basis, the judgment matrix is solved to obtain the relative weight coefficient. Explained 52 specific indicators, determined the content of indicator evaluation, and proposed specific scoring methods. Finally, the calculation method of the actual score of the green highway assessment is determined.

Based on the analysis of the construction characteristics of the Beijing-Shanghai Expressway, the green highway evaluation index system and evaluation model are used to evaluate the green road construction. It is calculated that the comprehensive score of the reconstruction and expansion project of Beijing-Shanghai Expressway is 81.2, reaching an excellent level.

\section{ACKNOWLEDGEMENTS}

We would like to thank the Shandong Transportation Technology Project "Research on Key Technologies of Green Highway of Jinghu Expressway" (2017B56) for research funding support. We also express appreciation to the Jilin Transportation Technology Project (2018-1-15) for research funding.

\section{REFERENCES}

1. Zhang qin. Research on Green Highway Evaluation Based on the Concept of Sustainable Development. Chongqing: Chongqing Jiaotong University, 2011.

2. Wang Ji, Ji Guang, Ma Jun. Research on Evaluation Index System and Evaluation Method of Green and Low Carbon Highway. Highway,2014,(7): 356-361.

3. Xie Zhi-ru, Yang Guang-ya, Fu Jin-shen. A Preliminary Study on Evaluation of Green and LowCarbon Highways of Sanxi Expressway in Henan Province. Highway Traffic Technology (Application Technology Edition),2016,8: 36-38

4. Liu Jie, Xu Honglei, Fu Yi-ming. Connotation Analysis and Evaluation Index System of Green Highway. Scientific research exchange, 2013,4: 3641.

5. Hao Pei-wen, Jiang Xiao-han, Shi Zai. Green highway concept and evaluation system. Road Machinery \& Construction Mechanization 2011, (5): 30-36.

6. Qin Xiao-chun, Shen Yi, Shao She-gang, Huang Yujie. Discussion on key technologies and applications of green highway construction under the concept of low carbon. Highway Traffic Technology (Application Technology Edition), 2010, (10): 308311.

7. Sun Lei, Cai Jie. Research on Evaluation Index System of Green Highway [1] Science \& Technology Information, 2012, (3): 491-492. 